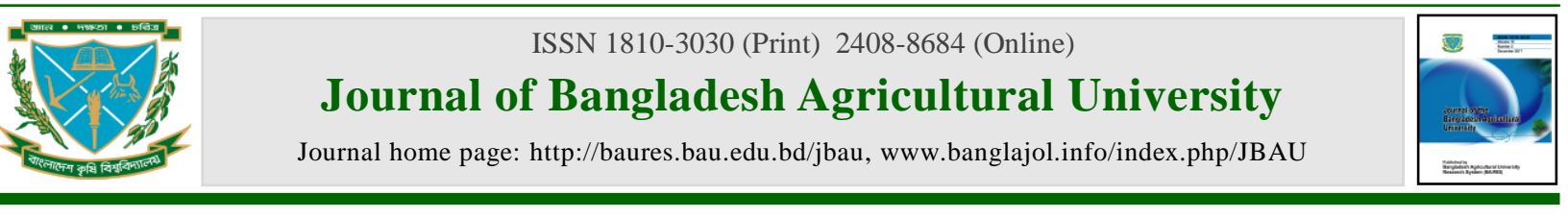

\title{
Effect of variety and planting density on weed dynamics and yield performance of transplant Aman rice
}

\author{
M. U. Salma, M. A. Salam, K. Hossen ${ }^{1}$ and M. R. J. Mou \\ Department of Agronomy, Bangladesh Agricultural University, Mymensingh-220, Bangladesh \\ ${ }^{1}$ Department of Agriculture, Noakhali Science and Technology University, Noakhali, Bangladesh
}

\begin{tabular}{|c|c|}
\hline ARTICLE INFO & Abstract \\
\hline $\begin{array}{l}\text { Article history: } \\
\text { Received: } 23 \text { October } 2017 \\
\text { Accepted: } 30 \text { November } 2017\end{array}$ & $\begin{array}{l}\text { The experiment was conducted at the Agronomy Field Laboratory, Bangladesh Agricultural University, } \\
\text { Mymensingh during Aman season from June to November } 2016 \text { to find out the effect of variety and } \\
\text { planting density on weed dynamics and yield performance of transplant Aman rice. The experiment } \\
\text { consisted of four varieties viz. Binadhan-7, BR } 25 \text {, BRRI dhan } 56 \text { and BRRI dhan } 62 \text { and four planting }\end{array}$ \\
\hline $\begin{array}{l}\text { Keywords: } \\
\text { Planting Density, T. Aman rice, } \\
\text { Variety, Weed dynamics, Yield }\end{array}$ & $\begin{array}{l}\text { density viz. } 25 \mathrm{~cm} \times 15 \mathrm{~cm}, 25 \mathrm{~cm} \times 10 \mathrm{~cm}, 20 \mathrm{~cm} \times 15 \mathrm{~cm} \text { and } 20 \mathrm{~cm} \times 10 \mathrm{~cm} \text {. The experiment was laid } \\
\text { out in a randomized complete block design with three replications. Variety exerted significant effect on } \\
\text { weed density and dry weight at different days after transplanting (DAT). The lowest weed density and dry } \\
\text { weight were observed in BR25 and the highest ones were observed in Binadhan-7. Weed population was } \\
\text { not significantly affected by planting density while weed dry weight was significantly affected and closer }\end{array}$ \\
\hline $\begin{array}{l}\text { Correspondence: } \\
\text { M.A. Salam } \\
\text { (salamma71@yahoo.com) }\end{array}$ & 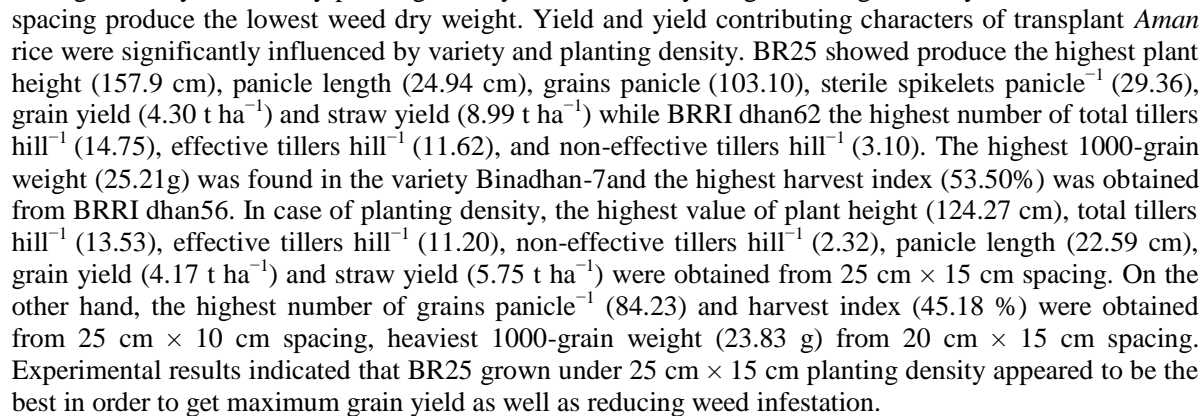 \\
\hline
\end{tabular}

\section{Introduction}

Agriculture is the single largest producing sector of the economy of Bangladesh since it comprises about $17.20 \%$ of the gross domestic product (GDP) and employs more than 45 percent of total labor force (BBS, 2016). Bangladesh is one of the most important rice growing countries of the world. Bangladesh ranks fourth in terms of rice production. During the year 2014-2015 rice covered an area of 11420.65 thousand hectares with a production of 34710 thousand $\mathrm{m}$. tons. Aman rice covers 13665 thousand acres with a production of 13190 thousand $\mathrm{m}$. tons (BBS, 2016). Aman is the second largest rice crop in the country in respect to the volume of production while boro rice ranks top in production. Aman rice covers more than half of the rice area accounting 5.53 million hectares with a production of 12.70 million tons. Average yield of Aman rice during the year 2014-15 has been estimated $2.39 \mathrm{t} \mathrm{ha}^{-1}$ which is $1.27 \%$ higher than that of previous year but which is still much low compared to the national rice average yield of $2.92 \mathrm{t} \mathrm{ha}^{-1}$ (BBS, 2016).

Among various factors responsible for yield loss, weeds are the greatest yield-limiting constraint to rice
(WARDA, 1996). Globally, actual yield losses due to pests have been estimated approximately $40 \%$ of which weeds caused the highest loss (32\%) (Rao et al., 2007). The rice crops are severely infested with weeds which can reduce the grain yields up to $16-48 \%$ for Aman rice (IRRI, 1998). Variety is an important genetic factor which contributes a lot for producing higher yield. Variety is the key component to produce higher yield of rice depending upon their differences in genetic constituents, input requirements and response, growth process and off course the prevailing environmental conditions during the growing season. The growth process of rice plants under a given agro-climatic condition differs with variety. The potential for increasing rice production strongly depends on the ability to integrate a better crop management for the different varieties into existing cultivation systems (Mikkelsen et al., 1995).

Optimum plant density of rice plays indirect but key role for absorption of necessary nutrients, well tillering, higher leaf area, etc. Improper spacing reduces the yield up to $25-30$ per cent. The optimum plant density ensures the plant to grow in their both aerial and underground 
parts through efficient utilization of solar radiation and nutrients (Miah et al., 1990). Planting density also exerts significant effect on reducing weed population (Rajkhowa et al., 2004; Eshaghi et al., 2013).

Rice variety plays a key role in suppressing weeds. Gogoi et al. (2000) reported that Akisali, a tall traditional cultivar, significantly reduced the weed dry matter accumulation compared with the other cultivars tested. Parvez et al. (2013) reported that weed population and dry weight were significantly affected by cultivar. They reported minimum weed growth in taller cultivar Nizershail and maximum weed growth in dwarf cultivar BRRI dhan41. Keeping the above points in views, the present study was, therefore, undertaken to find out the effect of variety and planting density on weed dynamics and yield performance of transplant Aman rice and to determine the interaction effect of variety and planting density on weed dynamics and the yield of transplant Aman rice.

\section{Materials and Methods}

The experiment was conducted at the Agronomy Field Laboratory, Bangladesh Agricultural University, Mymensingh during the transplant Aman season from June to November 2016 to find out the effect of variety and planting density on weed dynamics and yield performance of transplant Aman rice. The experimental field belongs to the agro-ecological region of the Old Brahmaputra Floodplain (AEZ-9 (FAO, 1988). The experiment field was medium high land having sandy loam soil with $\mathrm{pH}$ value 6.8 , low in organic matter and fertility level. The experiment included two factors, factor A- four varieties viz. Binadhan-7, BR25, BRRI dhan56 and BRRI dhan62 and factor B four planting density viz. $25 \mathrm{~cm} \times 15 \mathrm{~cm}, 25 \mathrm{~cm} \times 10 \mathrm{~cm}, 20 \mathrm{~cm} \times 15$ $\mathrm{cm}, 20 \mathrm{~cm} \times 10 \mathrm{~cm}$. The experiment was laid out in a two factorial randomized complete block design with three replications. The size of the unit plot was $10 \mathrm{~m}^{2}$ ( $4.0 \mathrm{~m} \times 2.5 \mathrm{~m})$. Seeds of Aman rice variety Binadhan-7, BR25, BRRI dhan56 and BRRI dhan62 were collected from the Agronomy Field Laboratory, BAU, Mymensingh. Seedlings were raised in well prepared nursery bed at the Agronomy Field Laboratory, BAU, Mymensingh. The experimental land was first opened with a power tiller. Later on, the land was prepared by ploughing and cross-ploughing with a country plough and subsequently leveled by laddering. All weeds and stubble were removed from the land. The field layout was done according to the experimental design on 24 July 2016. The field was fertilized with urea, triple super phosphate (TSP), muriate of potash (MoP) and gypsum were used as the source of nitrogen, phosphorus, potassium and sulphur at the rate of $165,60,110,70 \mathrm{~kg}$ $\mathrm{ha}^{-1}$, respectively. Twenty seven day old seedlings were uprooted from the nursery bed carefully and then transplanted on 25 July 2016 at the rate of three seedlings hill $^{-1}$ maintaining spacing as per experimental treatments. The crop was harvested at full maturity. Different varieties matured in different dates. The date of harvesting was confirmed when $90 \%$ of the grain became golden yellow in color. Binadhan-7 was harvested on 16 October, BRRI dhan56 and BRRI dhan62 on 20 October and BR25 on 06 November 2016. Five hills were randomly selected soon after transplanting and marked with bamboo sticks in each plot excluding border rows for determining growth parameters as well as yield and yield components. Data on weed population were collected from each plot at 20 , 35 and 50 DATs by using $0.25 \mathrm{~m} \times 0.25 \mathrm{~m}$ quadrate. The quadrate was placed three spots at random in each plots for recording weed data. The weeds within the quadrate were counted plot-wise and converted number $\mathrm{m}^{-2}$ by multiplying by four. The counted weeds plot ${ }^{-1}$ were dried first in the sun and then kept in an electric oven for 72 hours at $80^{\circ} \mathrm{C}$ temperature. The dry weight of each species was taken by an electrical balance and expressed in $\mathrm{g} \mathrm{m}^{-2}$. Data on different yield component were recorded from five consecutive selected hills from any row except border row in each plot. After sampling, a harvest area of central $1 \mathrm{~m} \times 1 \mathrm{~m}$ was selected from each unit plot. The harvested crop of each unit area was separately bundled, properly tagged and then brought to the threshing floor. The harvested crop was threshed by pedal thrasher and the weight was adjusted in $14 \%$ moisture content and straw were sundried properly. Finally grain and straw yields per unit area were converted to $\mathrm{t} \mathrm{ha}^{-1}$. Data recorded for growth, yield and yield contributing characters were compiled and tabulated in proper form for statistical analyses. Analysis of variance was done with the help of MSTAT-C computer package programme developed by Russel (1986). The mean differences among the treatments were adjudged by DMRT test (Gomez and Gomez, 1984).

\section{Results and Discussion}

\section{Effect of variety on weed density and dry weight}

Weed population and weed dry weight were significantly influenced by variety. The highest weed population (31.83) was found at 50 DAT from the variety Binadhan-7 and the lowest one was observed at 20 DAT (17.49) from the variety BR25. Maximum dry weight (23.05) was also found at 50 DAT from the variety Binadhan-7 and minimum dry weight (7.02) was observed at 20 DAT from the variety BR25 (Table 1). 
Table 1. Effect of variety on weed population and dry weight at different days after transplanting

\begin{tabular}{lcccccc}
\hline Variety & \multicolumn{3}{c}{$\begin{array}{c}\text { Weed population } \mathrm{m}^{-2} \\
\text { (no.) }\end{array}$} & & \multicolumn{2}{c}{$\begin{array}{c}\text { Dry weight } \mathrm{m}^{-2} \\
(\mathrm{~g})\end{array}$} \\
\cline { 2 - 7 } & $20 \mathrm{DAT}$ & $35 \mathrm{DAT}$ & $50 \mathrm{DAT}$ & $20 \mathrm{DAT}$ & $35 \mathrm{DAT}$ & $50 \mathrm{DAT}$ \\
\hline Binadhan-7 & $17.49 \mathrm{a} *$ & $26.91 \mathrm{a}$ & $31.83 \mathrm{a}$ & $9.22 \mathrm{a}$ & $13.70 \mathrm{a}$ & $23.05 \mathrm{a}$ \\
BR25 & $12.08 \mathrm{~b}$ & $21.73 \mathrm{~b}$ & $28.59 \mathrm{c}$ & $7.02 \mathrm{~b}$ & $10.96 \mathrm{~b}$ & $17.56 \mathrm{~b}$ \\
BRRI dhan56 & $16.36 \mathrm{a}$ & $26.74 \mathrm{a}$ & $29.86 \mathrm{bc}$ & $8.55 \mathrm{a}$ & $12.66 \mathrm{a}$ & $20.64 \mathrm{a}$ \\
BRRI dhan62 & $16.90 \mathrm{a}$ & $25.26 \mathrm{a}$ & $30.50 \mathrm{ab}$ & $8.83 \mathrm{a}$ & $13.96 \mathrm{a}$ & $21.58 \mathrm{a}$ \\
CV (\%) & 14.14 & 12.51 & 6.08 & 3.28 & 15.16 & 14.92 \\
Level of significance & 0.01 & 0.01 & 0.01 & 0.01 & 0.01 & 0.01 \\
\hline
\end{tabular}

*Mean values in a column having the same letter(s) do not differ significantly whereas mean values having different letter(s) differ significantly as per DMRT

Effect of planting density on weed density and dry weight

Weed density was influenced significantly at 20 DAT but non-significantly influenced at 35 DAT and 50 DATs by planting density. Weed dry weight was significantly influenced by planting density. However, the highest weed population (30.71) was found at 50
DAT in $25 \mathrm{~cm} \times 15 \mathrm{~cm}$ spacing and the lowest one was observed at 20 DAT (15.35) from $20 \mathrm{~cm} \times 10 \mathrm{~cm}$ spacing. Maximum weed dry weight (21.04) was also found at 50 DAT from spacing of $20 \mathrm{~cm} \times 15 \mathrm{~cm}$ and minimum weed dry weight (7.58) was observed at 20 DAT from planting density of $20 \mathrm{~cm} \times 10 \mathrm{~cm}$ (Table 2).

Table 2. Effect of planting density on weed population and dry weight at different days after transplanting

\begin{tabular}{lcccccc}
\hline Planting density & \multicolumn{3}{c}{$\begin{array}{c}\text { Weed population } \mathrm{m}^{-2} \\
\text { (no.) }\end{array}$} & \multicolumn{3}{c}{$\begin{array}{c}\text { Dry weight } \mathrm{m}^{-2} \\
(\mathrm{~g})\end{array}$} \\
\cline { 2 - 7 } & $20 \mathrm{DAT}$ & 35 DAT & 50 DAT & 20 DAT & 35 DAT & 50 DAT \\
\hline $25 \times 15 \mathrm{~cm}$ & $16.84 \mathrm{a}^{*}$ & 26.58 & 30.71 & $9.29^{\mathrm{a}}$ & $8.04 \mathrm{bc}$ & $23.53^{\mathrm{a}}$ \\
$25 \times 10 \mathrm{~cm}$ & $15.35 \mathrm{ab}$ & 25.42 & 30.45 & $13.94^{\mathrm{a}}$ & $12.50 \mathrm{ab}$ & $19.90 \mathrm{~b}$ \\
$20 \times 15 \mathrm{~cm}$ & $16.41 \mathrm{a}$ & 24.81 & 29.97 & $8.71 \mathrm{ab}$ & $13.09 \mathrm{ab}$ & $21.04 \mathrm{ab}$ \\
$20 \times 10 \mathrm{~cm}$ & $14.23 \mathrm{~b}$ & 23.84 & 29.65 & $7.58 \mathrm{c}$ & $11.74 \mathrm{~b}$ & $18.37 \mathrm{~b}$ \\
$\mathrm{CV}(\%)$ & 14.14 & 12.51 & 6.08 & 13.28 & 15.16 & 14.92 \\
Level of significance & 0.05 & $\mathrm{NS}$ & $\mathrm{NS}$ & 0.01 & 0.05 & 0.01 \\
\hline
\end{tabular}

*Mean values in a column having the same letter(s) do not differ significantly whereas mean values having different letter(s) differ significantly as per DMRT

$\mathrm{NS}=$ Not significant

Interaction effect of variety and planting density on weed density and dry weight

Weed density was significantly influenced and weed dry weight was influenced non-significantly at 20 DAT but significantly influenced at 35 DAT and 50 DAT by the interaction of variety $\times$ planting density. The highest weed density (33.16) was found at 50 DAT from Binadhan-7 at $25 \times 15 \mathrm{~cm}$ spacing and the lowest weed population was observed at 20 DAT (10.48) from (BR25 at $25 \mathrm{~cm} \times 10 \mathrm{~cm}$ spacing. The highest weed dry weight (26.19) was also found at 50 DAT from the variety
Binadhan-7 at $20 \mathrm{~cm} \times 15 \mathrm{~cm}$ spacing and the minimum weed dry weight (5.93) was observed at 20 DAT from BR25 at $25 \mathrm{~cm} \times 10 \mathrm{~cm}$ spacing This was because of wider spacing had greater opportunity to grow more weeds due to availability of space, water nutrient and other growth requirements than closer spacing. Similar research findings were also reported by Rajkhowa et al. (2004) and Eshaghi et al. (2013) who reported that closer spacing had lowest weed density and dry weight than wider spacing. 
Table 3. Interaction effect of variety and planting density on weed population and dry weight at different days after transplanting

\begin{tabular}{lcccccc}
\hline $\begin{array}{l}\text { Interaction } \\
(\text { variety } \times \text { planting }\end{array}$ & \multicolumn{3}{c}{$\begin{array}{c}\text { Weed population } \mathrm{m}^{-2} \\
\text { (no.) }\end{array}$} & \multicolumn{3}{c}{$\begin{array}{c}\text { Weed weight } \mathrm{m}^{-2} \\
\text { (g) }\end{array}$} \\
\cline { 2 - 7 } density) & 20 DAT & 35 DAT & 50 DAT & 20 DAT & 35 DAT & 50 DAT \\
\hline $\mathrm{V}_{1} \times \mathrm{S}_{1}$ & 17.97 & 30.20 & 33.16 & 9.70 & $14.55 \mathrm{ab} *$ & $23.42 \mathrm{ab}$ \\
$\mathrm{V}_{1} \times \mathrm{S}_{2}$ & 16.60 & 26.19 & 30.52 & 8.78 & $12.77 \mathrm{abcd}$ & $22.27 \mathrm{abc}$ \\
$\mathrm{V}_{1} \times \mathrm{S}_{3}$ & 19.77 & 26.38 & 31.33 & 10.22 & $15.51 \mathrm{a}$ & $26.19 \mathrm{a}$ \\
$\mathrm{V}_{1} \times \mathrm{S}_{4}$ & 15.62 & 24.88 & 32.29 & 8.10 & $11.96 \mathrm{abcd}$ & $20.31 \mathrm{abcdef}$ \\
$\mathrm{V}_{2} \times \mathrm{S}_{1}$ & 14.82 & 22.74 & 28.81 & 9.47 & $14.69 \mathrm{ab}$ & $24.27 \mathrm{ab}$ \\
$\mathrm{V}_{2} \times \mathrm{S}_{2}$ & 10.48 & 22.53 & 29.21 & 5.93 & $9.473 \mathrm{~d}$ & $15.21 \mathrm{ef}$ \\
$\mathrm{V}_{2} \times \mathrm{S}_{3}$ & 11.74 & 21.11 & 28.87 & 6.55 & $9.507 \mathrm{~d}$ & $15.86 \mathrm{def}$ \\
$\mathrm{V}_{2} \times \mathrm{S}_{4}$ & 11.27 & 20.53 & 27.45 & 6.11 & $10.16 \mathrm{~cd}$ & $14.90 \mathrm{f}$ \\
$\mathrm{V}_{3} \times \mathrm{S}_{1}$ & 16.66 & 28.52 & 30.54 & 8.61 & $11.57 \mathrm{bcd}$ & $22.58 \mathrm{abc}$ \\
$\mathrm{V}_{3} \times \mathrm{S}_{2}$ & 16.29 & 27.45 & 30.82 & 8.44 & $13.20 \mathrm{abcd}$ & $20.45 \mathrm{abcdef}$ \\
$\mathrm{V}_{3} \times \mathrm{S}_{3}$ & 16.29 & 25.87 & 28.94 & 8.53 & $12.28 \mathrm{abcd}$ & $18.48 \mathrm{bcdeg}$ \\
$\mathrm{V}_{3} \times \mathrm{S}_{4}$ & 16.19 & 25.12 & 29.16 & 8.62 & $13.59 \mathrm{abc}$ & $21.05 \mathrm{abcde}$ \\
$\mathrm{V}_{4} \times \mathrm{S}_{1}$ & 17.92 & 24.84 & 30.35 & 9.38 & $14.97 \mathrm{ab}$ & $23.84 \mathrm{ab}$ \\
$\mathrm{V}_{4} \times \mathrm{S}_{2}$ & 18.02 & 25.47 & 31.24 & 9.00 & $14.55 \mathrm{ab}$ & $21.66 \mathrm{abcd}$ \\
$\mathrm{V}_{4} \times \mathrm{S}_{3}$ & 17.82 & 25.89 & 30.73 & 9.53 & $15.07 \mathrm{ab}$ & $23.63 \mathrm{ab}$ \\
$\mathrm{V}_{4} \times \mathrm{S}_{4}$ & 13.86 & 24.83 & 29.68 & 7.40 & $11.26 \mathrm{bcd}$ & $17.20 \mathrm{cdef}$ \\
$\mathrm{CV} \%$ \% & 14.14 & 12.51 & 6.08 & 13.28 & 15.16 & 14.92 \\
Level of significance & NS & NS & NS & NS & 0.05 & 0.05 \\
\hline
\end{tabular}

*Mean values in a column having the same letter(s) do not differ significantly whereas mean values having different letter(s) differ significantly as per DMRT

NS= Not significant

Effect of variety on yield and yield components of transplant Aman rice

All the studied of crop and yield and yield contributing characters were significantly influenced by variety at $1 \%$ level of level of probability (Table 4). The tallest plant $(157.9 \mathrm{~cm})$ was obtained in variety BR25 and the shortest one $(99.72 \mathrm{~cm})$ was obtained in BRRI dhan62. The variation in plant height might be due to the heredity or varietal character. Similar results were also reported by Islam et al., 2012 and Tyeb et al., 2013. The highest number of total tillers hill ${ }^{-1}$ (14.75) was obtained from BRRI dhan62 and the lowest one (7.82) was found in BR25. The highest number of effective tillers hill ${ }^{-1}$ (11.62) was obtained from BRRI dhan62. The lowest number of effective tillers hill ${ }^{-1}$ (6.89) was found in BR25. Tyeb et al. (2013) showed that among four varieties of rice BRRI dhan52 showed superior performance over the other varieties (viz. BRRI dhan41, BRRI dhan46 and BRRI dhan51) in respect of number of effective tillers hill ${ }^{-1}$. The longest panicle $(24.94 \mathrm{~cm})$ was found in BR25 which was statistically identical with Binadhan-7. The shortest panicle $(21.26 \mathrm{~cm})$ was obtained from BRRI dhan62. Variation in panicle length among varieties was also reported by Kabir et al. (2004). The highest number of grains panicle ${ }^{-1}$ (103.1) was found in BR25, while the lowest one (58.65) from Binadhan-7 which was statistically similar with BRRI dhan62. Similar research finding was also reported by
Niu et al. (2001) where the authors observed variation in grains panicle ${ }^{-1}$ among the varieties. The highest number of sterile spikelets panicle ${ }^{-1}$ (29.36) was obtained from BR25 and the lowest one (17.93) was found in Binadhan-7 which was statistically similar with BRRI dhan62. Tyeb et al. (2013) showed variable number of sterile spikelets panicle ${ }^{-1}$ among varieties. The highest 1000-grain weight $(25.21 \mathrm{~g})$ was found from Binadhan7 and the lowest one $(21.86 \mathrm{~g})$ from BRRI dhan56 which was statistically at par with BR25 and BRRI dhan62. The highest grain yield $\left(4.30 \mathrm{t} \mathrm{ha}^{-1}\right)$ was obtained from $\mathrm{BR} 25$, whereas the lowest grain yield $\left(3.37 \mathrm{t} \mathrm{ha}^{-1}\right)$ was recorded from Binadhan-7. The highest grain yield in BR25 might be due to the result of longest panicle and highest number of grains panicle ${ }^{-1}$. The highest straw yield $\left(8.99 \mathrm{t} \mathrm{ha}^{-1}\right)$ was obtained from BR25. On the other hand, the lowest straw yield $\left(3.42 \mathrm{t} \mathrm{ha}^{-1}\right)$ was obtained from BRRI dhan56. The highest straw yield was obtained in BR25 might be due to the tallest plant height in BR25. Hossain et al. (2010) also obtained highest straw yield in BRRI dhan29 rice due to tallest plant and highest number of tillers hill ${ }^{-1}$. The highest harvest index $(53.50 \%)$ was obtained from BRRI dhan56 which was statistically at par with BRRI dhan62. The lowest harvest index (33.07\%) was recorded from BR25. Sultana et al. (2012) also reported variation in harvest index among the varieties. 
Table 4. Effect of variety on the crop character and yield component of transplant Aman rice

\begin{tabular}{|c|c|c|c|c|c|c|c|c|c|c|}
\hline Variety & $\begin{array}{c}\text { Plant } \\
\text { height } \\
(\mathrm{cm})\end{array}$ & $\begin{array}{l}\text { Total } \\
\text { tillers } \\
\text { hill }^{-1} \\
\text { (no). }\end{array}$ & $\begin{array}{c}\text { Effective } \\
\text { tillers } \\
\text { hill }^{-1} \\
\text { (no). }\end{array}$ & $\begin{array}{c}\text { Panicle } \\
\text { length } \\
(\mathrm{cm})\end{array}$ & $\begin{array}{c}\text { Grains } \\
\text { panicle }^{-1} \\
(\text { no }) .\end{array}$ & $\begin{array}{c}\text { Sterile } \\
\text { spikelets } \\
\text { panicle }{ }^{-1} \\
(\text { no }) .\end{array}$ & $\begin{array}{c}1000- \\
\text { grain } \\
\text { weight } \\
(\mathrm{g})\end{array}$ & $\begin{array}{l}\text { Grain } \\
\text { Yield } \\
\left(\mathrm{t} \mathrm{ha}^{-1)}\right.\end{array}$ & $\begin{array}{c}\text { Straw } \\
\text { Yield } \\
\left(\mathrm{t} \mathrm{ha}^{-1}\right)\end{array}$ & $\begin{array}{c}\text { Harvest } \\
\text { index } \\
(\%)\end{array}$ \\
\hline Binadhan-7 & $111.6 b^{*}$ & $11.75 b$ & $9.68 b$ & $221.85 a$ & $58.65 \mathrm{c}$ & $17.93 \mathrm{c}$ & $25.21 \mathrm{a}$ & $3.37 \mathrm{~b}$ & $5.07 \mathrm{~b}$ & $41.38 b$ \\
\hline BR25 & $157.9 \mathrm{a}$ & $7.82 \mathrm{c}$ & $6.89 c$ & $24.94 \mathrm{a}$ & $103.1 \mathrm{a}$ & $29.36 \mathrm{a}$ & $22.45 b$ & $4.30 \mathrm{a}$ & $8.99 \mathrm{a}$ & $33.07 \mathrm{c}$ \\
\hline BRRI dhan56 & $117.4 \mathrm{~b}$ & $11.82 \mathrm{~b}$ & $9.43 b$ & $21.47 \mathrm{~b}$ & $88.11 \mathrm{~b}$ & $23.20 \mathrm{~b}$ & $21.86 \mathrm{~b}$ & $4.01 \mathrm{a}$ & $3.42 \mathrm{c}$ & $53.50 \mathrm{a}$ \\
\hline BRRI dhan62 & $99.72 b$ & $14.75 \mathrm{a}$ & $11.62 \mathrm{a}$ & $21.26 \mathrm{~b}$ & $64.02 \mathrm{c}$ & $18.53 \mathrm{c}$ & $23.40 \mathrm{~b}$ & $4.12 \mathrm{a}$ & $4.25 b c$ & $49.57 \mathrm{a}$ \\
\hline $\mathrm{CV}(\%)$ & 11.52 & 16.28 & 13.97 & 5.81 & 18.42 & 23.20 & 8.09 & 16.22 & 27.73 & 12.67 \\
\hline Level of significance & 0.01 & 0.01 & 0.01 & 0.01 & 0.01 & 0.01 & 0.01 & 0.01 & 0.01 & 0.01 \\
\hline
\end{tabular}

*Mean values in a column having the same letter(s) do not differ significantly whereas mean values having different letter(s) differ significantly as per DMRT

$* *=$ Significant at $1 \%$ level of probability

Effect of planting density on yield and yield components of transplant Aman rice

Planting density had no significant effect on plant height. Numerically the tallest plant $(124.27 \mathrm{~cm})$ was obtained from $205 \mathrm{~cm} \times 15 \mathrm{~cm}$ ) spacing and the shortest one $(199.33 \mathrm{~cm})$ was produced the shortest plant $(119.33 \mathrm{~cm})$. Number total tillers hill ${ }^{-1}$ was significantly influenced by spacing. The highest number of total tillers hill ${ }^{-1}$ (13.50) was obtained from $25 \mathrm{~cm} \times 15 \mathrm{~cm}$ spacing and the lowest one (10.61) was found in $20 \mathrm{~cm} \times$ $10 \mathrm{~cm}$ spacing. The production of effective tillers hill ${ }^{-1}$ was significantly influenced by spacing. The highest number of effective tillers hill ${ }^{-1}$ (11.20) was obtained from $25 \mathrm{~cm} \times 15 \mathrm{~cm}$ spacing and the lowest one (8.43) was found in $20 \mathrm{~cm} \times 10 \mathrm{~cm}$ spacing. The highest number of total and effective tillers hill ${ }^{-1}$ in wider spacing might be due to having more sunlight thus more photosynthesis more space for producing more number of tillers. Spacing had no significant effect on panicle length. Numerically the longest panicle $(22.59 \mathrm{~cm})$ was found in $25 \mathrm{~cm} \times 15 \mathrm{~cm}$ spacing and the smallest one $(20.05 \mathrm{~cm})$ from $20 \mathrm{~cm} \times 10 \mathrm{~cm}$ spacing. Numerically the highest number of grains panicle ${ }^{-1}$ (84.23) was found in $25 \mathrm{~cm} \times 10 \mathrm{~cm}$ spacing and the lowest one (74.50) was found from $20 \mathrm{~cm} \times 10 \mathrm{~cm}$ spacing.
Numerically, the highest number of sterile spikelets panicle $^{-1}$ (23.43) was obtained from $20 \mathrm{~cm} \times 10 \mathrm{~cm}$ spacing and the lowest number of sterile spikelets panicle $^{-1}$ (20.03) was produced from $25 \mathrm{~cm} \times 15 \mathrm{~cm}$ spacing. 1000-grain weight was not significantly influenced by spacing. Alam (2004) reported that plant spacing had no influence on grain size because grain size was mainly controlled by gene not by environment. Spacing had significant effect on grain yield. The highest grain yield $\left(4.17 \mathrm{t} \mathrm{ha}^{-1}\right)$ was obtained from 25 $\mathrm{cm} \times 15 \mathrm{~cm}$ spacing whereas the lowest grain yield $\left(3.54 \mathrm{t} \mathrm{ha}^{-1}\right)$ was recorded from $20 \mathrm{~cm} \times 10 \mathrm{~cm}$ spacing. This highest grain yield might be due to highest number of total and effective tillers hill ${ }^{-1}$ in $25 \mathrm{~cm} \times 15 \mathrm{~cm}$ spacing. Significant variation on straw yield was not observed in transplant Aman rice due to the influence of spacing. Numerically the highest straw yield $(5.75 \mathrm{t}$ $\mathrm{ha}^{-1}$ ) was obtained from $25 \mathrm{~cm} \times 15 \mathrm{~cm}$ spacing. On the other hand the lowest straw yield $\left(4.85 \mathrm{t} \mathrm{ha}^{-1}\right)$ was obtained from $20 \mathrm{~cm} \times 10 \mathrm{~cm}$ ) spacing. It was found that spacing had no significant effect on harvest index. Numerically the highest harvest index $(45.18 \%)$ was obtained from $25 \mathrm{~cm} \times 10 \mathrm{~cm}$ spacing and the lowest one $(43.68 \%)$ from $20 \mathrm{~cm} \times 10 \mathrm{~cm}$ spacing.

Table 5. Effect of planting density on the crop character and yield component of transplant Aman rice

\begin{tabular}{|c|c|c|c|c|c|c|c|c|c|c|}
\hline planting density & $\begin{array}{c}\text { Plant } \\
\text { height } \\
(\mathrm{cm})\end{array}$ & $\begin{array}{c}\text { Total } \\
\text { tillers } \\
\text { hill }^{-1} \\
\text { (no). }\end{array}$ & $\begin{array}{c}\text { Effective } \\
\text { tillers } \\
\text { hill }^{-1} \\
\text { (no). }\end{array}$ & $\begin{array}{c}\text { Panicle } \\
\text { length } \\
(\mathrm{cm})\end{array}$ & $\begin{array}{c}\text { Grains } \\
\text { panicle }^{-1} \\
\text { (no). }\end{array}$ & $\begin{array}{c}\text { Sterile } \\
\text { spikelets } \\
\text { panicle } \\
\text { ( no). }\end{array}$ & $\begin{array}{c}\text { 1000- } \\
\text { grain } \\
\text { weight } \\
(\mathrm{g})\end{array}$ & $\begin{array}{c}\text { Grain } \\
\text { yield } \\
\left(\mathrm{t} \mathrm{ha}^{-1}\right)\end{array}$ & $\begin{array}{c}\text { Straw } \\
\text { yield } \\
\left(\mathrm{t} \mathrm{ha}^{-1}\right)\end{array}$ & $\begin{array}{c}\text { Harvest } \\
\text { index } \\
(\%)\end{array}$ \\
\hline $25 \times 15 \mathrm{~cm}$ & 124.27 & $13.5 \mathrm{a}$ & $11.20 \mathrm{a}$ & 22.59 & 76.95 & 20.03 & 23.35 & $4.17 \mathrm{a}$ & 5.75 & 44.39 \\
\hline $25 \times 10 \mathrm{~cm}$ & 121.43 & $11.05 \mathrm{~b}$ & $8.73 b$ & 22.47 & 84.23 & 22.99 & 22.97 & $4.03 \mathrm{ab}$ & 5.42 & 45.18 \\
\hline $20 \times 15 \mathrm{~cm}$ & 121.58 & $10.96 b$ & $9.27 \mathrm{~b}$ & 22.42 & 78.20 & 22.57 & 23.83 & $4.05 \mathrm{ab}$ & 5.71 & 44.26 \\
\hline $20 \times 10 \mathrm{~cm}$ & 119.33 & $10.61 b$ & $8.43 b$ & 22.05 & 74.50 & 23.43 & 22.78 & $3.54 \mathrm{~b}$ & 4.85 & 43.68 \\
\hline $\mathrm{CV}(\%)$ & 11.52 & 16.28 & 13.97 & 5.81 & 18.42 & 23.20 & 8.09 & 16.22 & 27.73 & 12.67 \\
\hline Level of significance & NS & 0.01 & 0.01 & NS & NS & NS & NS & 0.05 & NS & NS \\
\hline
\end{tabular}

*Mean values in a column having the same letter(s) do not differ significantly whereas mean values having different letter(s) differ significantly as per DMRT

NS = Not significant

Interaction effect of variety and planting density on yield and yield components of transplant Aman rice Plant height was not significantly influenced by the interaction of variety and spacing. Numerically the tallest plant $(165.60 \mathrm{~cm})$ was found in BR25 at $25 \mathrm{~cm} \times$ $10 \mathrm{~cm}$ spacing and the smallest one $(96.87 \mathrm{~cm})$ in BRRI dhan62 at $20 \mathrm{~cm} \times 10 \mathrm{~cm}$ spacing. The result of the study is in agreement with that of the finding of Akando 
(2007) who also observed insignificant influence of interaction of variety and spacing on plant height. Interaction of variety and spacing exhibited significant influence on number of total tillers hill ${ }^{-1}$. The highest number of total tillers hill ${ }^{-1}$ (15.93) was found from interaction of BRRI dhan62 at $25 \mathrm{~cm} \times 15 \mathrm{~cm}$ spacing which was statistically at par with Binadhan-7× $(25 \mathrm{~cm}$ $\times 15 \mathrm{~cm})$ spacing, BRRI dhan56 $\times(25 \mathrm{~cm} \times 15 \mathrm{~cm}$ spacing, BRRI dhan62 $\times 20 \mathrm{~cm} \times 15 \mathrm{~cm}$ spacing and BRRI dhan62 $\times(25 \mathrm{~cm} \times 10 \mathrm{~cm})$ spacing. The lowest number of total tillers hill ${ }^{-1}$ (5.97) was noticed in BR25 at $20 \mathrm{~cm} \times 10 \mathrm{~cm}$ spacing (Table 6). This research finding collaborates the finding of Tyeb et al. (2013) where they observed the highest number of tillers hill ${ }^{-1}$ with BRRI dhan 46 at $(25 \mathrm{~cm} \times 15 \mathrm{~cm})$ spacing. Number of effective tillers hill ${ }^{-1}$ varied significantly due to the interaction of variety and spacing. It was observed that the highest number of effective tillers hill ${ }^{-1}$ (13.40) was obtained from the interaction of Binadhan-7 at 25 $\mathrm{cm} \times 15 \mathrm{~cm}$ spacing and the lowest number of effective tillers hill $^{-1}$ (5.30) in BR25 at $20 \mathrm{~cm} \times 10 \mathrm{~cm}$ spacing. Tyeb et al. (2013) observed that BRRI dhan 46 at $25 \mathrm{~cm}$ $\times 15 \mathrm{~cm}$ spacing produced the highest number of effective tillers hill ${ }^{-1}$. Panicle length was significantly influenced by the interaction of variety and spacing. The highest panicle $(25.55 \mathrm{~cm})$ was resulted in BR25 at 20 $\mathrm{cm} \times 10 \mathrm{~cm}$ spacing which was statistically par with BR25 $\times(25 \mathrm{~cm} \times 10 \mathrm{~cm})$ spacing and BR25 at $25 \mathrm{~cm} \times$ $15 \mathrm{~cm}$ spacing. The smallest panicle $(20.31 \mathrm{~cm})$ was obtained from Binadhan-7 at $20 \mathrm{~cm} \times 10 \mathrm{~cm}$ spacing. The interaction effect of variety and spacing showed significant effect on straw yield at 5\% level of probability. The highest straw yield $\left(10.50 \mathrm{t} \mathrm{ha}^{-1}\right)$ was obtained from the interaction of BR25 at $25 \mathrm{~cm} \times 15 \mathrm{~cm}$ spacing, while the lowest straw yield $\left(3.21 \mathrm{t} \mathrm{ha}^{-1}\right)$ was found from the interaction of BRRI dhan56 at $25 \mathrm{~cm} \times$ $10 \mathrm{~cm}$ spacing. Due to close spacing highest number of plant population of BR25 produced highest straw yield at $25 \mathrm{~cm} \times 15 \mathrm{~cm}$ spacing. Moreover, taller plant of BR25 also favored the production of highest straw yield. Interaction of variety and spacing exhibited nonsignificant influence on harvest index. Numerically the highest harvest index $(56.65 \%)$ was found from BRRI dhan56 at $20 \mathrm{~cm} \times 15 \mathrm{~cm}$ spacing and the lowest one $(30.30 \%)$ was observed from the interaction of BR25 at $25 \mathrm{~cm} \times 10 \mathrm{~cm}$ spacing. From the results of the study it may be concluded that BR25 grown under $25 \mathrm{~cm} \times 15$ $\mathrm{cm}$ planting density appeared to be the best in order to get maximum grain yield as well as reducing weed infestation in T. Aman rice field. From this experimental result, it may be concluded that the highest grain yield $\left(5.10 \mathrm{t} \mathrm{ha}^{-1}\right)$ and straw yield $\left(10.50 \mathrm{t} \mathrm{ha}^{-1}\right)$ was recorded from the interaction of $\mathrm{V}_{2} \times \mathrm{S}_{1}(\mathrm{BR} 25$ at $25 \mathrm{~cm} \times 15 \mathrm{~cm}$ spacing). This result indicated that BR25 grown under $25 \mathrm{~cm} \times 15 \mathrm{~cm}$ planting density appeared to be the best in order to get maximum grain yield as well as reducing infestation.

Table 6. Interaction effect of variety and planting density on the crop character and yield component of transplant Aman rice

\begin{tabular}{|c|c|c|c|c|c|c|c|c|c|c|}
\hline $\begin{array}{c}\text { Interaction } \\
\text { (variety } \\
\times \text { planting } \\
\text { density) } \\
\end{array}$ & $\begin{array}{l}\text { Plant } \\
\text { height } \\
(\mathrm{cm})\end{array}$ & $\begin{array}{l}\text { Total tillers } \\
\text { hill }^{-1} \\
\text { (no). }\end{array}$ & $\begin{array}{l}\text { Effective } \\
\text { tillers hill } \\
\text { (no). }\end{array}$ & $\begin{array}{l}\text { Panicle } \\
\text { length } \\
(\mathrm{cm})\end{array}$ & $\begin{array}{c}\text { Grains } \\
\text { panicle }^{-1} \\
(\text { no }) .\end{array}$ & $\begin{array}{c}\text { Sterile } \\
\text { spikelets } \\
\text { panicle }^{-1} \\
(\text { no }) .\end{array}$ & $\begin{array}{c}1000- \\
\text { grain } \\
\text { weight } \\
(\mathrm{g}) \\
\end{array}$ & $\begin{array}{c}\text { Grain } \\
\text { yield } \\
\left(\mathrm{t} \mathrm{ha}^{-1}\right)\end{array}$ & $\begin{array}{c}\text { Straw } \\
\text { yield } \\
\left(\mathrm{t} \mathrm{ha}^{-1}\right)\end{array}$ & $\begin{array}{c}\text { Harvest } \\
\text { index } \\
(\%)\end{array}$ \\
\hline $\mathrm{V}_{1} \times \mathrm{S}_{1}$ & 107.67 & $15.87 \mathrm{a}^{*}$ & $13.40 \mathrm{a}$ & $22.94 b-d$ & 58.53 & 18.17 & 26.04 & 3.55 & $4.41 \mathrm{c}$ & 44.35 \\
\hline $\mathrm{V}_{1} \times \mathrm{S}_{2}$ & 107.07 & $11.53 \mathrm{~b}-\mathrm{e}$ & $8.87 \mathrm{de}$ & 20.99def & 55.43 & 16.75 & 25.45 & 3.62 & $4.44 c$ & 44.71 \\
\hline $\mathrm{V}_{1} \times \mathrm{S}_{3}$ & 130.20 & 9.07efg & $7.93 \mathrm{ef}$ & $23.17 \mathrm{a}-\mathrm{d}$ & 75.40 & 20.48 & 25.98 & 3.53 & $7.83 b$ & 32.51 \\
\hline $\mathrm{V}_{1} \times \mathrm{S}_{4}$ & 101.33 & $10.53 b-e$ & $8.53 \mathrm{de}$ & $20.31 \mathrm{f}$ & 45.24 & 16.31 & 23.37 & 2.78 & $3.570 \mathrm{c}$ & 43.94 \\
\hline $\mathrm{V}_{2} \times \mathrm{S}_{1}$ & 163.20 & 8.80efg & 7.73ef & $25.08 \mathrm{ab}$ & 102.7 & 22.397 & 22.20 & 5.10 & $10.50 \mathrm{a}$ & 32.15 \\
\hline $\mathrm{V}_{2} \times \mathrm{S}_{2}$ & 165.60 & $6.93 \mathrm{fg}$ & $5.93 \mathrm{fg}$ & $25.49 \mathrm{a}$ & 111.5 & 28.88 & 22.23 & 4.31 & $9.96 \mathrm{ab}$ & 30.30 \\
\hline $\mathrm{V}_{2} \times \mathrm{S}_{3}$ & 144.93 & $9.57 \mathrm{def}$ & 8.60de & $23.65 \mathrm{abc}$ & 88.41 & 28.93 & 23.27 & 4.10 & $7.71 b$ & 36.22 \\
\hline $\mathrm{V}_{2} \times \mathrm{S}_{4}$ & 157.93 & $5.97 \mathrm{~g}$ & $5.30 \mathrm{~g}$ & $25.55 \mathrm{a}$ & 109.8 & 37.24 & 22.12 & 3.67 & $7.80 \mathrm{~b}$ & 33.61 \\
\hline $\mathrm{V}_{3} \times \mathrm{S}_{1}$ & 123.73 & $13.53 \mathrm{ab}$ & $10.87 \mathrm{bcd}$ & 20.89def & 81.52 & 20.67 & 22.28 & 4.01 & $3.43 \mathrm{c}$ & 54.22 \\
\hline $\mathrm{V}_{3} \times \mathrm{S}_{2}$ & 111.93 & $10.53 b-e$ & $8.33 \mathrm{e}$ & $22.13 c-f$ & 100.1 & 27.53 & 21.89 & 3.79 & $3.21 \mathrm{c}$ & 53.68 \\
\hline $\mathrm{V}_{3} \times \mathrm{S}_{3}$ & 114.33 & $9.93 \mathrm{c}-\mathrm{f}$ & 8.40de & $21.07 \mathrm{def}$ & 81.07 & 22.33 & 21.13 & 4.70 & $3.59 \mathrm{c}$ & 56.65 \\
\hline $\mathrm{V}_{3} \times \mathrm{S}_{4}$ & 119.67 & $13.27 \mathrm{abc}$ & $10.13 \mathrm{cde}$ & $21.79 \mathrm{c}-\mathrm{f}$ & 89.77 & 22.28 & 22.15 & 3.52 & $3.45 \mathrm{c}$ & 49.44 \\
\hline $\mathrm{V}_{4} \times \mathrm{S}_{1}$ & 102.47 & $15.93 \mathrm{a}$ & $12.80 \mathrm{ab}$ & $21.44 c-f$ & 65.0 & 18.89 & 22.87 & 4.03 & $4.66 c$ & 46.86 \\
\hline $\mathrm{V}_{4} \times \mathrm{S}_{2}$ & 101.13 & $15.13 \mathrm{a}$ & $11.80 \mathrm{abc}$ & $21.27 \mathrm{c}-\mathrm{f}$ & 69.88 & 18.80 & 22.31 & 4.40 & $4.07 \mathrm{c}$ & 52.04 \\
\hline $\mathrm{V}_{4} \times \mathrm{S}_{3}$ & 96.87 & $15.27 \mathrm{a}$ & $12.13 \mathrm{abc}$ & $21.79 c-f$ & 67.92 & 18.53 & 24.94 & 3.86 & $3.71 \mathrm{c}$ & 51.66 \\
\hline $\mathrm{V}_{4} \times \mathrm{S}_{4}$ & 98.40 & $12.67 \mathrm{a}-\mathrm{d}$ & $9.733 \mathrm{cde}$ & $20.56 \mathrm{ef}$ & 53.20 & 17.89 & 23.46 & 4.17 & $4.57 \mathrm{c}$ & 47.72 \\
\hline CV (\%) & 11.52 & 16.28 & 13.97 & 5.81 & 18.42 & 23.20 & 8.09 & 16.22 & 27.73 & 12.67 \\
\hline $\begin{array}{l}\text { Level of } \\
\text { significance }\end{array}$ & NS & 0.05 & 0.01 & 0.05 & NS & NS & NS & NS & 0.05 & NS \\
\hline
\end{tabular}

*Mean values in a column having the same letter(s) do not differ significantly whereas mean values having different letter(s) differ significantly as per DMRT

$\mathrm{NS}=$ Not significant 


\section{Acknowledgements}

The authors are grateful to the Ministry of Science and Technology for the financial support through NST Fellowship.

\section{References}

Akando, M. A. 2007. Effect of variety and spacing on the growth, yield and yield contributing characters of aromatic rice. M. S. Thesis, Dept. of Agron. Bangladesh Agril. Univ., Mymensingh. pp. 22-65.

Alam, M. K. 2004. Effect of nitrogen and plant spacing on the growth and yield of transplant amanrice cv. Binadhan-4. M. S. Thesis, Dept. Agron., Bangladesh Agril. Univ., Mymensingh. pp. 59.

BBS (Bangladesh Bureau of Statistics). 2016. Statistical Year Book of Bangladesh. Bangladesh Bur. Stat., Stat. Div., Min. Plan., Govt. People's Repub. Bangladesh, Dhaka. pp. 32-50.

Eshaghi, M., Mobaser, H., Mousavi, A.A. and Mahmudi J. 2013. Effected of planting density on controlling weeds in two cultivars of rice. Intl. J. Agric. Crop Sci. 13(6): 275-379.

FAO (Food and Agriculture Organization) 1988. Land Resources Appraisal of Bangladesh for Agricultural Development. Report 2. Agro-ecological Regions of Bangladesh. FAO. Rome. pp. 212.

Gogoi, A. K.; Rajkhowa, D. J.; Kandali, R. 2000. Effect of varieties and weed-control practices on rice (Oryza sativa) productivity and weed growth. Indian J. Agron. 45(3): 580-585.

Gomez, K. A. and Gomez, A. A. 1984.Ducan's Multiple Range Test. Statistical Procedures for Agricultural Research. 2nd Edn., A Wiley Inter-SciencePublication, Jhon Wiley and Sons, New York. p. 202-215.

Hossain, M. S., Monshi, F. I., Kamal, A. M. A. and Miah, M. F. 2010. Grain yield and protein content of transplant amanrice as influenced by variety and rate of nitrogen. J. Agrofor. Environ. 3 (2): 235-238.

IRRI (International Rice Research Institute), 1998. Annual Report for 1990. Intl. Rice Res. Inst., Los Banos, Philippines. pp. 246.
Kabir, M. E., Kabir, M. R., Jahan, M. S. and Das, G. G. 2004. Yield performance of three aromatic fine rice in a coastal medium high land. Asian J. Plant Sci. 3(5): 561-563.

Miah, M. H. N., Karim, M. A., Rahman, M. S. and Islam, M. S. 1990. Performance of Nitrogen nutrients under different row spacing. Bangladesh J. Train. Dev. 3(2):31-34.

Mikkelsen, D. S., Jayaweera, G. R. and Rolston, D. E. 1995. Nitrogen fertilization practices of low land rice culture. Nitrogen Fertilization in the Environment. J. Agron. 12(2):171-223.

Niu, J., Li, Y., Zhang, W., Niu, Z. and Zhou, M. 2001. High yielding and good quality Tianjin 1244.Japonica hybrid cultivar series. Intl. Rice Res. 26(1): pp.12.

Parvez, M.S., Salam, M.A., Kato-Noguchi H. and Begum, M. 2013. Effect of cultivar and weeding regime on the performance of transplant aman rice. Intl. J. Agric. Crop Sci. 6(11): 654- 666 .

Rao, A. N., Johnson D. E., Sivaprasad B., Ladha J. K. and Mortimer A. M. 2007. Weed management in direct seeded rice. AdvAgron. 93: 153-255.

Rajkhowa, D.J., Barua I.C. and Gogoi A.K. 2004. Effect of plant population density and weeding regime on weed dynamics and performance of Basmati rice. Ind. J. Weed Sci. 36(3): $111-115$.

Russel, D. F. 1986. MSTAT-C package programme.Crop and Soil Sci. Dept., Michigan State Univ., USA. Gomez, K. A. and Gomez, A. A. 1984.Statistical Procedure for Agricultural Research.2nd ed. John Wiley and Sons. New York. pp. 64.

Sultana, M., Kader, M. A., Islam, M. S. and Zaman, F. 2012. Performance of transplanted aman rice under various levels and sources of nitrogen application. Bangladesh J. Environ. Sci. 23: 202-206.

Tyeb, A., Paul, S. K. and Samad, M. A. 2013.Performance of variety and spacing on the yield and yield contributing characters of transplanted aman rice. J. Agrofor. Environ. 7(1): 57-60, 2013.

WARDA (West Africa Rice Development Association), 1996.Annual Report for 1995. West Africa Rice Development Association, Bouake, Cote d'Ivoire, Cali (Colombia International Center for Tropical Agriculture, Rome (Italy): Food and Agriculture Organization, pp. 253. 